Тийна ЛНННАС, Р. МНКЕЛСААР, Хелбе НУТТ, О. КИРРЕТ

\title{
ГЛИКОЛЬМЕТАКРИЛАТНЫЕ ГЕЛИ КАК НОСИТЕЛИ ДЛЯ АФИННОЙ ХРОМАТОГРАФИИ АНТИТЕЛ
}

Tiina LINNAS, R. MIKELSAAR, Helbe NUTT, O. KIRRET, GLOKOOLMETAKRULAATGEELID KUI KANDJAD ANTIKEHADE AFFIINSUSKROMATOGRAAFIAS

Tiina LINNAS, R. MIKELSAAR, Helbe NUTT, O. KIRRET. GLYCOLMETACRYLATE GELS AS THE CARRIERS FOR THE AFFINITY CHROMATOGRAPHY OF ANTIBODIES

Гликольметакрилатные гели (ГМГ), известные под торговым названием Сферон Р 1000, после их активации бромцианом, применены в качестве носителей для афинной хроматографии трипсина и ингибитора трипсина [ $\left.{ }^{1}\right]$. Нами изучена возможность применения этих гелей после их активации 2-амино-4,6-дихлортриазином для афинной хроматографии антител.

\section{Материал и методика}

Гидроксиалкилметакрилатгель (ГМГ) Сферон Р 1000 (0,0630,100 мм) получен от фирмы «Лахема» (Чехословакия). 2-амино-4,6дихлортриазин синтезирован в лаборатории. Для иммунизации кроликов [2] применены сывороточный альбумин (бычий) марки «А» и суспензия тканевых антигенов поджелудочной железы [3].

Активацию ГМГ 2-амино-4,6-дихлортриазином проводили по следующей методике. 1 г ГМГ обрабатывали в течение 15 мин 3 н. раствором $\mathrm{NaOH}\left[{ }^{2}\right]$, затем отсасывали и к продукту добавляли смесь из 50 мл ацетонового раствора и 0,5 - 2-амино-4,6-дихлортриазина, полученную при комнатной температуре в течение 5-10 мин. Продукт промывали ацетоном, смесью уксусная кислота-вода-ацетон, водой и ацетоном и высушивали в вакууме.

Связывание антигенов сывороточного альбумина и тканевых антител поджелудочной железы к ГМГ проводили в среде боратного буфера при комнатной температуре (количество белка 10-20 мг на 100 мг ГМГ). Время связывания $2-4$.

Для определения количества антител в колонку с иммуносорбентом $(0,9 \times 5 \mathrm{~cm})$ вносили 1 мл сыворотки. После инкубации в течение 15 мин физиологическим раствором при $\mathrm{pH} 7,4$ вымывали неспецифические белки, а при рН 3,2 - специфические. Количество белка определяли по адсорбцин при $280 \mu$. 


\section{Обсуждение результатов}

Для разработки условий связывания антигенов со Сфероном Р 1000 , активированным 2-амино-4,6-дихлортриазином, и определения на этом

Количество антител на Сфероне Р 1000 , активированном производными хлортриазина

\begin{tabular}{c|c|c|c|c}
\hline Носитель & $\begin{array}{c}\text { Элементарный } \\
\text { состав, \% }\end{array}$ & \begin{tabular}{c} 
Белок, \\
мг/2 \\
\cline { 2 - 3 }
\end{tabular} & $\begin{array}{c}\text { Кол-во } \\
\text { антител, } \\
\text { мг/2 } \\
\text { носителя }\end{array}$ & $\mathrm{Cl}$
\end{tabular}

$\begin{array}{llllr}1^{*} & \overline{-} & \overline{11} & - & 8,0 \\ 2 & 2,21 & 1,14 & - & 5,0 \\ 3 & 0,56 & 0,69 & 30 & 13,0 \\ 4 & 6,77 & 1,87 & 56 & 15,0 \\ 5 & 3,10 & 0,30 & 25 & 10,4 \\ 6^{* *} & 5,15 & 4,60 & - & 7,5 \\ 7^{* *} & 0,5 & 0,80 & - & 15,0\end{array}$

Примечани е. * Сферон Р 1000 активирован дихлорангидридом адипиновой кислоты, антитела связаны на матрицу изонитральным методом [4].

** Сферон Р 1000 активирован 2,4,6-трихлортриазином.

носителе антител в качестве модельного антигена использован бычий сывороточный альбумин марки «А».

Количество связанных с носителем антител зависит от химического состава его (таблица). С помощью 2-амино4,6-дихлортриазина на 1 г носителя связывается до 50 мг антигена. Максимальное количество антител, которое может быть связано на 1 г активированного Сферона Р 1000 составляет примерно 15 мг.

Наши данные показывают, что емкость активированного Сферона Р 1000 ниже емкости других носителей, применяемых для определения количества антител в сыворотках крови. Однако благодаря хорошим свойствам Сферона Р 1000 при работе на колоночном режиме малая емкость не мешает использовать его для афинной хроматографии антител. Колонка со связанным антигеном работает устойчиво и не теряет активности в течение полугода (рис. 1).

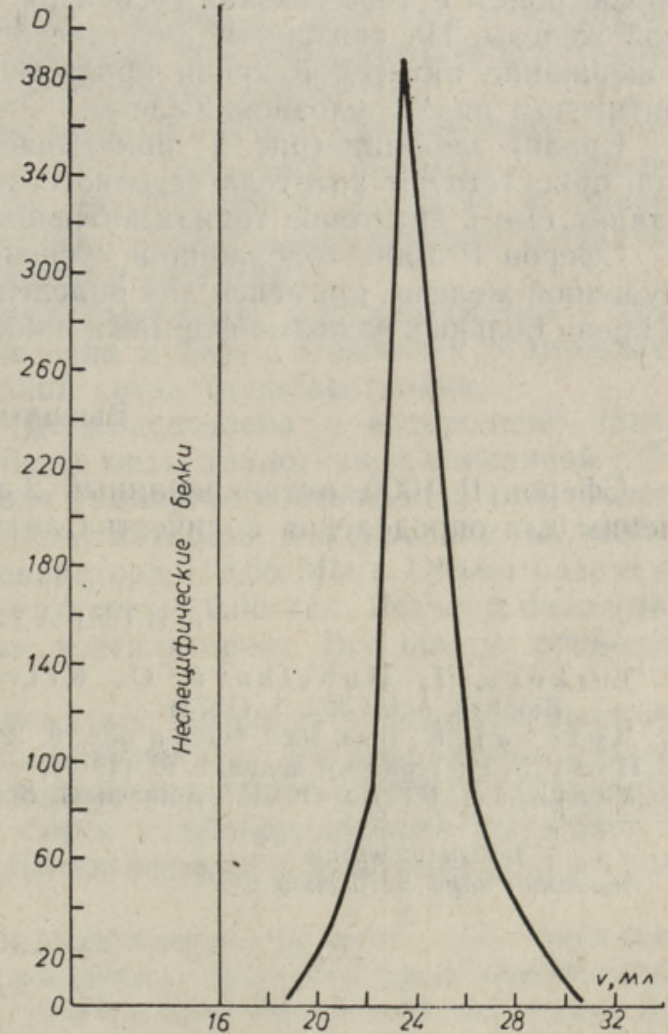

Рнс. 1. Хроматограмма элюации сыворотки крови с антиальбумином. 


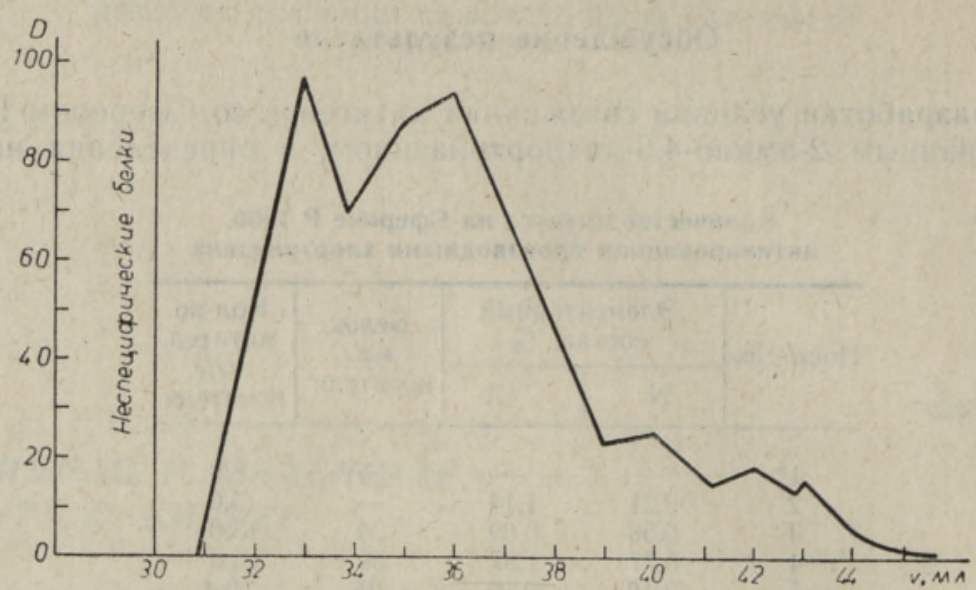

Рис. 2. Хроматограмма сыворотки крови кроликов.

Далее была предпринята попытка применить Сферон Р 1000, активированный 2-амино-4,6-дихлортриазином, для определения антител в крови больных панкреатитом. Для этого по приведенной выше методике со Сфероном Р 1000 связана суспензия тканевых антигенов поджелудочной железы. На связанном антигене определено общее количественное содержание антител в крови кроликов, иммунизированных тканевым антигеном поджелудочной железы.

Кривая элюации (рис. 2) показывает, что в сыворотке крови кроликов присутствуют антитела не одного, а нескольких разных видов. Связанная смесь антигенов теряла активность после $15-20$ циклов работы.

Сферон Р 1000, содержащий суспензию тканевых антигенов поджелудочной железы, применен для определения общего количества антител в крови больных разными формами панкреатита.

\section{Выводы}

Сферон Р 1000, активированный 2-амино-4,6-дихлортриазином, применим для опрєделения количества антител в сыворотках крови.

\section{Л И Т Р Р А У Р А}

1. Turková, I., Hubalková, O., Krivaková, M., Cóupek, I., Biochim. Biophys. Acta, 322, 1 (1973).

2. Михкл а Е. К., Бюл. эксп. биол. и мед., 9, 122 (1965).

3. Н у т т X. Р., Терапевт, архив, 7, 51 (1970).

4. Vretbla d, P., Axén, R., Ảcta chem. Scand., 8, 2769 (1973).

Институт химии

Академии наук Эстонской ССР
Поступила в редакцию 27/I 1977 